\title{
The Rise, Fall and Potential for a Rebirth of Receivership in UK Corporate
}

\section{Law}

\begin{abstract}
In this article, we explore diverse forms of receivership in order to demonstrate the extent of the continued or potential utility of this institution in UK Corporate Law. We do this by placing the historical origins of receivership alongside its contemporary manifestations in both solvent and insolvent scenarios. In so doing, we present a nuanced picture of receivership as a process that, in specie and - by reference to outcomes in other corporate insolvency law procedures - in substance, continues to provide protection for creditors (and other stakeholders) in modern commercial transactions.
\end{abstract}

Keywords: receiver; receivership; administrative receivership; administration; prepacks

\section{A. Introduction}

This article uses the term "receivership" generically to refer to a number of situations in which a person may be appointed as receiver by the court - suo moto or under statute, or by a legal or natural person under the terms of a contract, for the purpose of protecting, managing, or realising the value of property (including an undertaking). Thus, our definition of receivership is wide enough to cover court-appointed receivers, ${ }^{1}$ non-administrative receivership, ${ }^{2}$ and administrative receiverships. ${ }^{3}$ It encompasses out-of-court appointments of receivers as contractual expedients by debenture holders looking to enforce their security. ${ }^{4}$ These diverse categories of receivership constitute the basis of our discussions. This serendipity allows the institution to react to change.

\footnotetext{
${ }^{1}$ For example, under Senior Courts Act 1981, s 37 and Criminal Justice Act 1988, s 77(8).

${ }^{2}$ Law of Property Act 1925, s 101. See also Insolvency (England and Wales) Rules 2016, r 4.22.

${ }^{3}$ Insolvency Act 1986, s 29(2). See also Insolvency (England and Wales) Rules 2016, part 4.

${ }^{4}$ See for example, Day v Tiuta International Ltd [2014] EWCA Civ 1246.
} 
Understandably, modern discourse on receivership has centred on the use of administrative receivership in insolvency. This is clearly linked to two related issues: firstly, the putative value of the procedure to the reorganisation of distressed companies; and, secondly, questions on the value of the floating charge, particularly its impact on the company and unsecured creditors in insolvency. ${ }^{5}$ The Enterprise Act 2002 (EA), however, made sweeping changes to administrative receivership. The impetus behind these changes was the Government's discomfort with the power of a floating chargee to appoint an administrative receiver. ${ }^{6}$ Contractual receivership had been long established as a remedy available to a floating chargee even where the debtor had already gone into winding up. ${ }^{7}$ This remedy was also available prior to crystallisation of the floating charge, although the appointment of an administrative receiver will typically constitute a crystallisation event. Appointing a receiver allows a creditor to enforce security in circumstances such as the debtor's insolvency ${ }^{8}$ or default. ${ }^{9}$ Such enforcement in insolvency through an administrative receiver was seen to be prejudicial to the company and its unsecured creditors. This is because the administrative receiver was taken to be primarily accountable to his appointing creditor $^{10}-\mathrm{a}$ feature incompatible with the collective nature of an ideal insolvency regime. ${ }^{11}$ Further, the extant administration procedure was perceived to be ineffective due inter alia to

\footnotetext{
${ }^{5}$.Report of the Review Committee on Insolvency Law and Practice (Cmnd 8558, 1982), (The Cork Report), para 495 onwards; J Armour and S Frisby, 'Rethinking Receivership' (2001) 21 OJLS 73. ${ }^{6}$ Department of Trade and Industry ('DTI'), Insolvency - A Second Chance (White Paper, Cmnd 5234, 2001).

${ }^{7}$ Re Henry Pound, Son \& Hutchins (1889) 42 ChD 402.

${ }^{8}$ Re Panama, New Zealand and Australia Royal Mail Company (1869-70) 5 Ch App 318, 322-323.

${ }^{9}$ Re Florence Land and Public Works Co., ex p Moor (1878) 10 ChD 530, 541.

${ }^{10}$ DTI, Insolvency - A Second Chance n.5 above, paras 2.2-2.3; Re B Johnson \& Co (Builders) Ltd [1955] Ch 634; Gomba Holdings v Homan [1986] BCLC 331; Silven Property v Royal Bank of Scotland [2004] 1 WLR 997.

${ }^{11}$ It had been argued that administrative receivership should not be classed as an insolvency procedure because it does not involve the exercise of class rights as demanded by a collective insolvency regime. See F Oditah, 'Assets and treatments of Claims in Insolvency' (1992) 108 LQR 459, 460-461. This also explains its exclusion under EU Regulation on Insolvency Proceedings (2015/848) and the UNCITRAL Cross-Border Insolvency Regulations (SI 2006/1030).
} 
the ability of a floating charge holder to frustrate an administration order by appointing a receiver.

For these reasons, the EA introduced section 72A of the Insolvency Act 1986 which largely ${ }^{12}$ abolished the power of a floating chargee to appoint an administrative receiver. Given that the prohibition relates to floating charges created after 15 September 2003, the effect is to give the holder of a floating charge created before this date the right to appoint an administrator $^{13}$ along with his contractual right to appoint an administrative receiver. The same goes for an administrative receiver appointed by a floating charge created under the exceptions. ${ }^{14}$ The extent to which such chargees will exercise the power to appoint a receiver instead of making an out-of-court administrator appointment will also be explored in this article. In any event, this statutory inroad into contractual arrangements for the creation of proprietary interests represented a marked shift in UK Corporate Law's treatment of such interests. $^{15}$

Recent post-EA data on administrative receivership in England and Wales clearly illustrate its progressive extinction as a distinct insolvency procedure: ${ }^{16} 2012$ (32); 2013 (17); 2014 (22); 2015 (11); 2016 (5); 2017 (2); and 2018 (1). Data on its use in Scotland and Northern Ireland postulate a similar conclusion. ${ }^{17}$ It is therefore apt to consider not only any residual utility of administrative receivership, but, more importantly, the value of other forms of receivership.

\footnotetext{
${ }^{12}$ For capital markets and public utilities exceptions, see Insolvency Act 1986, ss 72B-72H.

${ }^{13}$ ibid, Sch B1, para 14.

${ }^{14}$ Note, however, Feetum $v$ Levy [2005] EWCA Civ 1601 where it was held that the appointment of the administrative receiver was invalid as it did not fall within the exception in s.72E.

${ }^{15}$ One of the high-water marks of UK Corporate Law's pro-secured creditor attitude is the decision in Re David Lloyd \& Co (1877) 6 ChD 339.

${ }^{16}$ Data available at <https://www.gov.uk/government/collections/insolvency-statistics> accessed 14 May 2018. As far as insolvency frameworks go, this is a trend that fits with the non-recognition of any form of receivership as collective insolvency proceedings under the EU Regulation on Insolvency Proceedings (2015/848) or the UNCITRAL Cross-Border Insolvency Regulations 2006 (SI 2006/1030).

17 ibid.
} 
The remainder of this article will be divided into four sections. Section B will discuss the historical origins of receivership in UK Corporate Law. Section C will explore the continued utility of administrative and LPA receivership in insolvency. Section D will consider diverse uses of receivership in non-insolvency contexts. Section E contains some concluding thoughts on the future of receivership and some of the issues raised by its continued use in UK Corporate Law.

\section{B. The Genesis of Receivership in UK Corporate Law}

This historical account provides an intellectual prism through which the value and nature of the continued usage of receivership in a corporate law context can be constructed. This, of course, or ought to be an important consideration should Parliament consider further legislation in this area.

The roots of receivership lie in ancient law of property, in particular in the Normaninstituted feudal system of landholding. ${ }^{18}$ This heralded the practice of mortgagees securing their investments through the appointment of a receiver in the event of a mortgagor's default. ${ }^{19}$ This was done to obviate pitfalls associated with the mortgagee directly or obliquely taking possession of the property. ${ }^{20}$ This contractual form of receivership was eventually recognised by a series of legislative provisions, ${ }^{21}$ culminating in sections 101 and 102 of the Law of Property Act (LPA) 1925. These provisions implied in mortgage agreements made by deed the power of the mortgagee to appoint a receiver of the income of

\footnotetext{
${ }^{18}$ H Rajak 'Old Institutions Die Hard' (2013) 329 Co LN 1. See also DP Waddilove, 'Emmanuel College v Evans (1626) and the History of Mortgages' (2014) 73 CLJ 142.

${ }^{19}$ JG Reyes, 'The Swinging Pendulum of Equity: How History and Custom Shaped the Development of the Receivership Statute in Illinois' (2013) 44 LUCLJ 1019, 1040.

${ }^{20}$ Gaskell v Gosling [1896] 1 QB 669, 691-692.

${ }^{21}$ See Trustee Act 1860 (Lord Cranworth's Act, 23 \& 24 Vict c 145), s 11; Conveyancing Act 1881, ss 19-20, 24.
} 
the mortgaged property. ${ }^{22}$ Two things should be noted about these provisions. First, is that this power to appoint the receiver is statutorily implied to the extent that it has not been excluded by the parties' agreement as expressed in the mortgage deed. ${ }^{23}$ The asymmetry in the bargaining strengths of the mortgagee and mortgagor makes such exclusion implausible in typical commercial transactions. Second is that, mirroring the pre-statutory position, a receiver so appointed is purely a receiver of income and has no power of management or sale of the mortgaged property unless the statutory power is varied or extended by the mortgage deed. ${ }^{24}$

It would seem that this default position that a receiver lacked managerial powers was down to an accepted differentiation in the office of a receiver of property and that of a manager, or 'receiver and manager' of property. ${ }^{25}$ The latter type of office-holders were more suitable where the mortgaged assets were connected to an undertaking, which was necessary to carry on for a period of time in order to preserve the mortgagee's pecuniary interest in the charged assets. This is where the floating charge qua security over the whole or substantially the whole of a company's undertaking comes into this historical equation.

The raison d'être for the floating charge was commercial pragmatism. Companies, particularly smaller ones, required more capital after the industrial revolution. ${ }^{26}$ However, prevailing security devices at the time, such as mortgages and pledges, were unsuitable for financing businesses which typically held more current or circulating assets than fixed assets. ${ }^{27}$ Taking a fixed security over assets which the debtor will subsequently dispose of

\footnotetext{
${ }^{22}$ Popularly termed 'LPA Receivers'; LPA 1925, s 101(1)(iii). LPA receivers do not have to be licensed insolvency practitioners.

${ }^{23}$ ibid, s 101(4).

${ }^{24}$ ibid, s 101(1)(iii), (3).

${ }^{25}$ See for example, Re Manchester and Milford Rly Co (1880) 14 ChD 645, 653; Re P [2000] 1 WLR 473, 483 .

${ }^{26}$ RR Pennington, 'The Genesis of the Floating Charge' (1960) 23 MLR 630.

${ }^{27}$ ibid, 631; Buchler v Talbot [2004] 2 AC 298, [2] (Lord Nicholls).
} 
was plainly inconvenient for both parties. ${ }^{28}$ As the nineteenth century judiciary began to recognise this extensive form of security as one that permitted the company to continue to carry on its business in the usual way and deal with the charged assets, ${ }^{29}$ it was also accepted that this permission would be withdrawn by the chargee on the debtor's default. But given the nature of assets involved, there was also a clear need on such default to engage in sale, management or trading in order to turn current assets like stock in trade or executory contracts into cash for the benefit of the chargee. Thus, it became the practice for the chargee appointing a receiver of income to also install the same person as a manager of the defaulting company's business. ${ }^{30}$ The facility to make such appointment eventually found its way into loan contracts as a condition for obtaining the loan; the receiver's power of management being constituted for the purpose of preserving and realising assets comprised in the security for the benefit of the debenture holder. ${ }^{31}$ This heralded the institution of the receiver and manager, which later became known as administrative receivership. ${ }^{32}$

A number of ancillary points will now be made on the historical trajectory of receivership. An emerging theme from the account above is that, historically, commercial receivership was predicated on the enforcement of security rights. The same could be said about modern commercial receivership. Administrative receivership and LPA receivership concern the enforcement of private security rights. It also seems possible to use receivership to enforce something akin to a statutory security interest. ${ }^{33}$ Even in non-insolvency contexts

\footnotetext{
${ }^{28} \mathrm{R}$ Goode and L Gullifer, Goode and Gullifer on Legal Problems of Credit and Security $\left(6^{\text {th }}\right.$ edn, Sweet \& Maxwell 2017), para 4-02.

${ }^{29}$ Re Panama, New Zealand and Australia Royal Mail Company (1869-70) 5 Ch App 318; Re Florence Land and Public Works Co., exp Moor (1878) 10 ChD 530.

${ }^{30}$ LG Doyle, Administrative Receivership: Law and Practice (FT Law \& Tax 1995), p 5.

${ }^{31}$ Re B Johnson \& Co (Builders) Ltd [1955] Ch 634, 661-663 (Jenkins LJ).

${ }^{32}$ Insolvency Act 1986, s 29(2). The term "administrative receiver" emerged in policy discussions after the publication of the Cork Report.

${ }^{33}$ For example, an administrator's charge in respect of remuneration and expenses under Insolvency Act 1986, Sch B1 para 99(3). See Re MK Airlines Ltd [2012] EWHC 1018 (Ch); Re Hotel Company 42 The Calls Ltd; Whitfield v Al Jaber [2013] EWHC 3925 (Ch).
} 
where the emphasis is not on enforcement of security rights, receivership is mainly used to preserve individuals' rights in property pending the resolution of a dispute relating to the property. ${ }^{34}$ However, it is this emphasis on the individual rather than the collective that constitutes receivership's bane in corporate insolvency.

The Cork Committee gave support to the institution of receivership, but it noted the concerns about wider accountability. Whilst rejecting a change in the law of accountability, it confirmed the fiduciary position of the receiver when dealing with charged assets and it favoured greater transparency through the use of a creditors' committee. ${ }^{35}$

It is important to be clear that the concern around a receiver's accountability to wider stakeholders (like creditors and the borrowing company itself) in an insolvency scenario is not, if construed properly, about the absence of a legal duty to these stakeholders. Rather, it is about the precise nature of the duty that the receiver owes. ${ }^{36}$ Indeed, since a receiver deals with both the security and charged assets, and the interests of other stakeholders attach to the latter, a receiver owes these stakeholders a duty to exercise powers conferred upon him by the debenture in good faith and for the purpose for which they were conferred, i.e. to obtain repayment of the debt owed to the debenture holder. ${ }^{37}$ However, the receiver does not owe these stakeholders a general common law duty of care since such duty is plainly inconsistent with equity's historical conception that the charge or mortgage is merely a security for repayment of debt. ${ }^{38}$ Such duty of care could, however, arise - as an extension of the obligation to act in good faith - where the receiver has elected to perform specific functions

\footnotetext{
${ }^{34}$ For example, Senior Courts Act 1981, s 37. See also Re Smith [2017] EWHC 3334 (Comm).

${ }^{35}$ The Cork Report, paras 453-454 and 481.

${ }^{36}$ A useful summary of a receiver's duties is to be found in Ahmad v Bank of Scotland [2016] EWCA Civ 602 at [38].

${ }^{37}$ Re B Johnson \& Co (Builders) Ltd [1955] Ch 634; Downsview Nominees Ltd v First City Corp Ltd [1993] AC 295; Devon Commercial Property Limited v Robert Adrian Barnett [2019] EWHC 700 (Ch).

${ }^{38}$ ibid. Moreover, a mortgagee can still appoint a receiver even if there was a conflict of interest and any such appointment is not invalid; see Jennings v Quinn [2018] NI Ch 17.
} 
like operating the debtor's business. ${ }^{39}$ It would also arise if the receiver decides to exercise a power of sale, binding the receiver to obtain a proper (or the best) price. ${ }^{40}$ The actual and potential existence of these duties suggest that receivership is not a selfish procedure in its entirety. Moreover, as will be discussed below, there are other emphases on the collective criterion in both insolvency and non-insolvency (including non-commercial) contexts of receivership, with the growth of the rescue culture ${ }^{41}$ and ability to use a receiver to realise a property's value for the benefit of the state ${ }^{42}$ being prime exemplars.

A second point is that while persons appointed as receivers and managers may be administrative receivers, this is not always the case. For such persons to be administrative receivers, they must be appointed by floating charge holders as receivers and managers of a "company". ${ }^{43}$ By extension where the relevant entity to which a receiver and manager is appointed is not a company, such as a registered industrial and provident society, the appointment is not affected by the prohibition against appointment of administrative receivers. $^{44}$

Thirdly, the power to appoint a receiver in Scotland was not available until floating charges were themselves recognised under Scottish law. ${ }^{45}$ Thus, the Companies (Floating

\footnotetext{
${ }^{39}$ Medforth v Blake [2000] Ch 86 at 102-103. See also G McCormack, 'Receiverships and the Rescue Culture' (2000) 2 CFILR 229.

${ }^{40}$ Cuckmere Brick Co v Mutual Finance [1971] Ch 949; McDonagh v Bank of Scotland [2018] EWHC 3262 (Ch); Close Brothers Ltd v AIS (Marine) 2 Ltd [2018] EWHC B14 (Admlty). In exercising the power of sale, the receiver cannot pass any better title than the chargor; see Courtwood Holdings SA v Woodley Properties Ltd [2018] EWHC 2163(Ch) at [175].

${ }^{41}$ The Cork Report, para 495.

${ }^{42}$ See Criminal Justice Act 188, s 77(8); Re A [2007] EWHC 2549 (QB). See also the power to appoint a receiver under section 26 of the Drug Trafficking Act 1994 to prevent disposal of "realisable property". However, such receiver is not conferred with a general power of sale, particularly while the defendant has not been convicted. See Re Piper [2000] 1 WLR 473. See also Proceeds of Crime Act (POCA) 2002, ss 48, 50 and 69. The 'POCA' receivership would not be of the company as such but could be over the shares in a company owned by the defendant.

${ }^{43}$ Re Dairy Farmers of Britain Ltd [2009] EWHC 1389 (Ch). Moreover, it goes without saying that such receivers and/managers would also be administrative receivers if the charge extends to the whole (or substantially the whole) of a company's property. See Insolvency Act 1986, s 29(2)(a).

44 ibid.

${ }^{45}$ Companies (Floating Charges) (Scotland) Act 1961.
} 
Charges and Receivers) (Scotland) Act 1972 made it competent for the holder of a floating charge to appoint a receiver or joint receivers over such part of the company's property as is subject to the charge. ${ }^{46}$ In Northern Ireland, the institution of receivership is codified in the Insolvency (Northern Ireland) Order $1989 .{ }^{47}$

Finally, we should point out the purposive and supportive interpretations provided by courts to questions on settling creditor claims in non-administrative receiverships of structured investment vehicles. These cases ${ }^{48}$ emerged post-Enterprise Act, at a time when predictions on the extinction of receivership were rife. Admittedly, some of these investment vehicles became distressed as a result of exposure to the then tumultuous US investment market and the use of fixed-charge receivership to deal with them may be attributable to certain advantages, including greater secured creditor control, tax advantages, and lack of insolvency practitioner scrutiny. ${ }^{49}$ But the point is that these decisions, in helping the receivers to arrive at a commercially sensible result that best mirrors the parties' intentions, can only make receivership a further attraction in these niche contexts.

\section{The Continued Utility of Administrative Receivership in Insolvency Law}

In Section A above, we explored the basis for the abolition of administrative receivership under the EA. As the data reproduced in that section revealed, there are still scarce incidences of administrative receiverships. Those receiverships are attributable to the exemptions to the

\footnotetext{
${ }^{46}$ ss 11, 15. See now Insolvency Act 1986, ss 50-71 (as amended); MacMillan v T Leith Developments Ltd (In Receivership and Liquidation) [2017] CSIH 23.

${ }^{47}$ SI 1989/2405 (NI 19), arts 40-59 (as amended).

${ }^{48}$ Re Cheyne Finance Plc (in rec.) (No.1) [2007] EWHC 2116 (Ch); Re Cheyne Finance Plc (in rec.) (No.2) [2007] EWHC 2402 (Ch); Re Whistlejacket Capital Ltd (in rec.) [2008] EWCA Civ 575; Re Golden Key Ltd [2009] EWCA Civ 636.

${ }^{49}$ D Milman 'The Continuing Institution of Receivership and its Relationship to other Security Enforcement Tools and Recovery Devices in English Law' (2009) 247 Company Law Newsletter 1, 3.
} 
abolition of receiverships and pre-15 September 2003 floating charges ${ }^{50}$ It is instructive, however, to note that a trawl of The Gazette ${ }^{51}$ and Companies House ${ }^{52}$ in 2018 revealed copious instances of pre-2003 floating charge administrative receivership appointments.

Some examples of these appointments are now set out in table below.

\begin{tabular}{|c|c|c|c|c|}
\hline & Company Name & Date of Charge $^{53}$ & Appointment Date & Appointor \\
\hline 1. & QU-VAL construction & $\begin{array}{l}15 \text { November } \\
1979\end{array}$ & 1 December 2017 & Ulster Bank \\
\hline 2. & Riveroak Associates Ltd & $\begin{array}{l}24 \text { September } \\
1996\end{array}$ & 20 March 2017 & Promontoria (Arrow) Ltd \\
\hline 3. & DC Cook Manchester Ltd & 8 August 1994 & 26 February 2016 & Natwest Bank \\
\hline 4. & $\begin{array}{l}\text { Manchester Wholesale } \\
\text { Flowers }\end{array}$ & 5 July 1995 & 19 April 2016 & Natwest Bank \\
\hline 5. & $\begin{array}{l}\text { North East Property } \\
\text { Holdings }\end{array}$ & 8 June 2001 & 1 December 2015 & $\begin{array}{l}\text { Promontoria (Chestnut) } \\
\text { Ltd }\end{array}$ \\
\hline 6. & Classmulti Ltd & 6 September 1996 & 27 November 2015 & $\begin{array}{l}\text { Promontoria (Henrico) } \\
\text { Ltd }\end{array}$ \\
\hline 7. & Sevenhills Estates Ltd & 1 December 1998 & 20 November 2015 & $\begin{array}{l}\text { Promontoria (Chestnut) } \\
\text { Ltd }\end{array}$ \\
\hline 8. & Joe Richards Ltd & 25 October 1994 & 5 August 2015 & Natwest Bank \\
\hline 9. & Beale \& Cole Ltd & 22 March 1996 & 8 December 2014 & Natwest Bank \\
\hline 10. & Pearl Motor Yachts Ltd & 15 May 2002 & 13 November 2014 & Natural person \\
\hline
\end{tabular}

\footnotetext{
${ }^{50}$ Insolvency Act 1986, ss 72A(4), 72B-72H; D Milman 'The Continuing Institution of Receivership and its Relationship to other Security Enforcement Tools and Recovery Devices in English Law', n.52 above, 1.

$51<\mathrm{https}: / /$ www.thegazette.co.uk/insolvency>

$52<$ https://beta.companieshouse.gov.uk/>

${ }^{53}$ The date here is the date of delivery (registration) of the charge to the Companies House rather than actual date of creation. This is because the delivery of the charge is crucial to the validity of the charge in insolvency and against other creditors. See Companies Act 2006, Part 25.
} 


\begin{tabular}{|c|c|c|c|c|}
\hline 11. & Freeclaim IDC Plc & 28 June 1995 & 2 October 2014 & Clydesdale Bank \\
\hline 12. & Wandle Holdings Plc & 1 April 1998 & 17 October 2013 & $\begin{array}{l}\text { National Asset Loan } \\
\text { Mgmt }\end{array}$ \\
\hline 13. & Roger Haydock \& Co Ltd & 3 October 1983 & 12 August 2013 & Lloyds Bank \\
\hline 14. & Three Queens Hotel Ltd & 15 June 1990 & 2 April 2013 & Natwest Bank \\
\hline 15. & Agora Shopping Centres Ltd & 13 March 2003 & 11 January 2013 & Bank of Scotland \\
\hline 16. & Adam \& Sons Finance Ltd & 22 May 2001 & 15 October 2012 & Natwest Bank \\
\hline 17. & Land Charter Homes Ltd & 1 November 1999 & 1 June 2012 & Natwest Bank \\
\hline 18. & Henron's Park Investments & $\begin{array}{l}17 \text { September } \\
1996\end{array}$ & 24 February 2012 & Natwest Bank \\
\hline 19. & Lincoln Group Ltd & 25 August 1999 & 5 January 2012 & Bank of Cyprus \\
\hline 20. & Peak Press Ltd & 20 May 1994 & 14 November 2011 & Royal Bank of Scotland \\
\hline 21. & EMH International Ltd & 12 August 1997 & 7 July 2011 & Natwest Bank \\
\hline 22. & Hickteam Ltd & $\begin{array}{l}30 \text { November } \\
2002\end{array}$ & 28 January 2011 & Yorkshire Bank \\
\hline 23. & Peakway Holdings Ltd & 23 June 1998 & 23 September 2010 & Natwest Bank \\
\hline 24. & Talepine Ltd & $\begin{array}{l}20 \text { December } \\
1995\end{array}$ & 7 May 2010 & Barclays Bank \\
\hline 25. & Southwell Business Park Ltd & 5 January 2000 & 17 March 2010 & Natwest Bank \\
\hline
\end{tabular}

The data in the table above is the product of a random selection of administrative receivership appointments since 2010 . In that selection process, we only encountered a couple of post-15 September 2003 floating charge appointments. ${ }^{54}$ A further striking point is that the bulk of pre-15 September 2003 floating charge appointments were made by bank debenture holders

\footnotetext{
${ }^{54}$ Excalibur Funding No.1 Plc (Charge: 2 June 2008; Appointor: US Bank Trustees) and BWH Realisations 2012 Ltd (Charge: 31 July 2010; Appointor: Barclays Bank).
} 
or by parties connected to such banks. ${ }^{55}$ The fact that banks, at least historically, were repeat users of receivership to enforce their security rights is not a novel discovery. ${ }^{56}$ What is novel is the realisation that despite the streamlined administration regime providing banks with much of the benefits of administrative receivership, ${ }^{57}$ certain banks have continued to use receivership as a debt enforcement mechanism. This may be tied to the similarities between the two procedures, which we examine below, as well as the lack of a time limit in completing receivership unlike in administration. ${ }^{58}$

The remainder of this section is devoted to the contention that administrative receivership continues to thrive in substance, rather than in form, in UK corporate insolvency law. This contention, which we support with qualitative data, is based on the following issues: the use of pre-packaged administrations; out-of-court appointment of an administrator; the use and effect of the objectives of administration in paragraphs 3(1)(b) and 3(1)(c) of schedule B1; and the duty of an administrator to insolvency stakeholders in comparison to that of an administrative receiver. These issues are now examined in turn.

\section{i. Pre-Packaged Administrations: A Blast from the Past}

For the purpose of this discussion, it is useful to start with two salient points: first, that much of the consternation surrounding the institution of administrative receivership was tied to the perception that the procedure was largely run by and for the benefit of the floating charge holder; and second, recent empirical study of administrations conducted by one of the

\footnotetext{
${ }^{55}$ For example, the appointments that were made by Promontoria in the table above were made by them as assignees of the charge from banks like Allied Irish Banks and Clydesdale Bank.

${ }^{56}$ See G McCormack, 'The Priority of Secured Credit: An Anglo-American Perspective' [2003] JBL 389-419, 416.

${ }^{57}$ See the discussions that follow in section $\mathrm{C}$ (i)-(ii) below.

${ }^{58}$ Insolvency Act 19876, Sch B1, para 76.
} 
authors ${ }^{59}$ revealed that the most common objective pursued by office-holders was achieving a better result for the company's creditors as a whole ${ }^{60}$ via an asset or business sale.

Pre-packs involve a rescue of an insolvent's business by achieving a going concern sale of the business. In a pre-packaged administration, the terms of the sale of a company's business are arranged before the commencement of administration and executed as soon as the administrator is appointed. The legality of pre-packs is settled ${ }^{61}$ and it would seem that the commercial rationale for them hinges on the notion that insolvency is sometimes valuestripping (rather than value-enhancing), thus making it difficult to broker a rescue of the company or its business for meaningful value within an insolvency procedure. ${ }^{62}$ It should therefore be hardly surprising that pre-packs have grown in recent years. Indeed, around onein-three administrations now conducted are pre-packaged administrations. ${ }^{63}$ Other empirical research shows that most pre-packaged administrations involve SMEs. ${ }^{64}$

The growth of pre-packs is interesting in light of the criticisms that enshrouded administrative receivership, and which led to its abolition. This is because, much like administrative receivership, pre-packs have the following features: (1) the sale of the insolvent's business, an asset to which the general body of creditors are collectively entitled,

\footnotetext{
${ }^{59}$ [omitted for peer review].

${ }^{60}$ Insolvency Act 1986, Sch B1, para 3(1)(b).

${ }^{61}$ See, for example, Re DKLL Solicitors [2007] EWHC 2067 (Ch); Re Johnson Machine and Tool Co Ltd [2010] EWHC 582 (Ch).

${ }^{62}$ S Frisby, 'Insolvency Law and Insolvency Practice: Principles and Pragmatism Diverge?' Current Legal Problems 64(1) 349-397, 378.

${ }^{63}$ See Graham Review into Pre-Pack Administration (June 2014) <https://www.gov.uk/government/publications/graham-review-into-pre-pack-administration> (accessed 13 September 2018). In 2015-2016, pre-packs represented 22\% of all administrations and $28 \%$ in 2017. See Pre-pack Pool Annual Review <https://www.prepackpool.co.uk/uploads/files/documents/Pre-pack-Pool-Annual-Review-2017.pdf> accessed 13 September 2018.

${ }^{64}$ See P Walton and C Umfreville, 'Pre-Pack Empirical Research: Characteristic and Outcome Analysis of Pre-Pack Administration (Final Report to the Graham Review, April 2014). This research showed that around $93 \%$ of 500 pre-packs in 2010 involved SMEs based on number of employees, and $90 \%$ based on turnover. However, pre-packs of big High Street chains like House of Fraser might be the exception that proves the rule.
} 
is brokered outside a collective insolvency procedure; (2) the consent of the general body of creditors to such sale is not obtained in advance; (3) pre-packs are typically marshalled by the floating charge holder since it holds an extensive security interest over the company's undertaking, ${ }^{65}$ and (4) the floating charge holder is usually a beneficiary of a pre-pack as costs are reduced (compared to trading administrations) and recoupment of debt is accelerated. ${ }^{66}$ One may therefore suggest that the benefits of administrative receivership to secured creditors are replicated by pre-packed administrations. ${ }^{67}$ To put it differently, if prepacks are largely influenced by secured creditors, the growth of pre-packs suggests that many administrations are controlled by such creditors.

This control by a creditor with a floating charge is achieved in two ways. First is floating chargees' ability to make an out-of-court appointment of an administrator ${ }^{68}$ or, as is sometimes the case, to ensure that the company or its directors appoint their nominee (or an office-holder whom they approve of ). ${ }^{69}$ Thus, floating chargees in a direct or oblique way achieve an appointment scenario that is similar to administrative receivership in the sense that they either do not have to engage in extensive monitoring of the office-holder who may feel obliged to the chargee ${ }^{70}$ or, any monitoring or control will be welcomed by the office-holder given his familiarity with the chargee and the need to ensure future business. The second way is a product of the compulsory funding regime that requires costs and expenses of the insolvency process to be top-sliced from floating charge assets. ${ }^{71}$ This means that floating chargees have a strong incentive to closely scrutinise the management activities of the office-

\footnotetext{
${ }^{65}$ L Gullifer and J Payne, Corporate Finance Law: Principles and Policy ( $2^{\text {nd }}$ edn, Hart 2015), 7.5.1.4. ${ }^{66}$ ibid.

${ }^{67}$ The pre-packaged administration is said to be a descendant of administrative receivership; see Frisby, Insolvency Law and Insolvency Practice: Principles and Pragmatism Diverge? n.65 above. ${ }^{68}$ Insolvency Act 1986, Sch B1, para 14.

${ }^{69}$ Akintola, 'What is left of the Floating Charge? An Empirical Outlook', n.62 above, 405-406.

${ }^{70}$ Such feeling may be more acute where the administration is run for the purpose of making a distribution to one or more secured creditors; Insolvency Act 1986, Sch B1, para 3(1(c).

${ }^{71}$ ibid, sch B1, para 99.
} 
holder. Research shows that floating chargees control fees and monitor the incurring of other expenses. ${ }^{72}$ In addition, it has also been suggested that in pre-packaged administrations, floating chargees, as lead creditors, exhibit control by brokering (without reference to other creditors) the sale of the company's business. ${ }^{73}$

This, however, does not always produce a negative insolvency outcome. The benefit of secured creditor control within insolvency is properly manifested where the secured creditor uses its position to bring about a change in corporate management in order to keep the business afloat, or to maximise realisations for the general body of creditors through the selling of the business as a going concern. The overseeing of a pre-pack sale by the charge holder leads to reduced costs that might improve realisations for the general body of creditors, even though it would usually accelerate recovery for the chargee. ${ }^{74}$ This is an outcome that is manifestly similar to administrative receivership's. ${ }^{75}$

Therefore, while we may have abolished the form of administrative receivership, it would seem that the essence of receivership is very much alive in the reformed administration procedure. Indeed, one could contend that pre-packaged administrations are essentially receiverships under another name. This sounds counterintuitive in light of the abolition of administrative receivership and explicates why pre-packs came under criticism in recent

\footnotetext{
${ }^{72}$ E Kempson, Review of Insolvency Practitioner Fees: Report to the Insolvency Service, 4.2.1. Available at $\langle$ https://www.gov.uk/government/publications/insolvency-practitioner-fees-a-review $\rangle$ accessed 13 September 2018. See also Office of Fair Trading, The Market for Corporate Insolvency Practitioners: A Market Study (2010).

${ }^{73}$ See Gullifer and Payne, Corporate Finance Law: Principles and Policy, n.68 above, 7.3.3.4 and 7.5.1.4.

${ }^{74} \mathrm{ibid}$. Moreover, the absence of altruism in the secured creditor's control of pre-packaged administrations or the receivership process should not, in itself, dislodge the utility of these identical procedures. Analysis of the analogous benefit of this control in receivership, sometimes called the 'concentrated creditor governance' theory of receivership, will be found in V Finch and D Milman, Corporate Insolvency Law: Perspectives and Principles (3rd edn, CUP 2017), ch 8, p.288 onwards. ${ }^{75}$ Note, however, that a chargee may be liable if it interferes with the conduct of the administration to a degree that goes beyond the legitimate involvement that a secured creditor could expect to have in the process. See Davey v Money and Anor [2018] EWHC 766 (Ch) at [706]. This also applies in receiverships - American Express International Banking Corp. v Hurley (1986) 2 BCC 98993.
} 
years. ${ }^{76}$ Nevertheless, we must equally recognise the value of pre-packs in salvaging the business of distressed companies. It is this recognition that led to much of the recent reforms to pre-packs with a view to make them more transparent, and to improve accountability to the general body of creditors in the process. ${ }^{77}$ Much of the reforms to pre-packs directly concern 'phoenix sales'; that is to say the sale of a company's business to 'connected parties'. Such sales can now be submitted for scrutiny to the Pre-pack Pool in order to improve the transparency of the sale. ${ }^{78}$ However, recent figures from the pool show a drop in referrals from over one-in-four in 2015-2016, to one-in-ten in $2017 .{ }^{79}$

\section{ii. Administration $v$ Administrative Receivership: $A$ Distinction without a Difference?}

What follows is a comparison of certain features of the streamlined administration regime and administrative receivership. These features relate to the objectives of administration and an administrator's duty in contradistinction to that of an administrative receiver. The comparison is accentuated by the views of interviewees ${ }^{80}$ from one of the authors' empirical research into the subject.

The starting point is that few administrations are initiated with the primary objective of rescuing the company as a going concern. ${ }^{81}$ Rather, most administrations have the objective of achieving a better result for the company's creditors as a whole than would be

\footnotetext{
${ }^{76}$ Pre-packs have been criticised for lack of transparency, and causing damage to the interest of unsecured creditors who are unable to influence the decision to sell or the value of the sale.

${ }^{77}$ See for example, Statement of Insolvency Practice ('SIP 16'). A new SIP 16 was introduced on 1 November 2015.

${ }^{78}$ Graham Review into Pre-Pack Administration (June 2014).

${ }^{79}$ Pre-pack Pool Annual Review <https://www.prepackpool.co.uk/uploads/files/documents/Pre-packPool-Annual-Review-2017.pdf $>$ accessed 13 September 2018.

${ }^{80}$ The interviews were conducted in 2015 and form part of the analysis in [omitted for peer review] Interviewees include a legal practitioner, a representative of one of the big-five banks ('lender') and insolvency practitioners.

${ }^{81}$ Insolvency Act 1986, Sch B1, para 3(1)(a).
} 
likely if the company were wound up. ${ }^{82}$ This objective is often achieved by an asset sale or, less commonly, a going concern business sale/rescue. Achieving an asset or business sale in order to acquire funds for distribution to creditors is a well-known badge of receivership. ${ }^{83}$ This outcome blurs the distinction between the two insolvency procedures and is consistent with earlier empirical research which discovered that both procedures usually have asset and business sales as outcomes. ${ }^{84}$

Further, it is worth exploring the duty of an administrator in the context of the rationale behind the abolition of administrative receivership. It will be recalled that a key rationale was the apparent lack of accountability of the receiver to anyone else other than the appointing creditor. ${ }^{85}$ This was seen by Parliament as incompatible with a collective insolvency regime and its desire to encourage rescue of failing companies. Thus, the duty of an administrator to perform his functions in the interests of the company's creditors as a whole was introduced. ${ }^{86}$ One interviewee, a lawyer, shared the following views on this rationale:

\footnotetext{
"No, it is nonsense! ... It was totally misconceived because what they essentially said, as I read it, was that 'we have discovered that where an administrator is appointed, unsecured creditors do better than where a receiver is appointed'. And of course the reason for that was that in one case there was a floating charge and in the other there wasn't ... If the receiver had assets worth $£ 100$ - he has got a secured creditor of $£ 60$ and he sells them for $£ 80$, then he is clearly liable to the liquidator on behalf of the unsecured creditors for the shortfall, isn't he? And to say that a receiver is
}

\footnotetext{
${ }^{82}$ ibid, para 3(1)(b).

${ }^{83}$ S Frisby, Report on Insolvency Outcomes (June 2006), pp.57-59.

${ }^{84}$ ibid.

${ }^{85}$ DTI, Insolvency - A Second Chance, paras 2.2-2.3.

${ }^{86}$ Insolvency Act 1986, Sch B1, para 3(2).
} 
not liable to anyone other than his appointor is just wrong in my view; it doesn't state the law correctly. So this idea that you have got the receiver who can go and do what the heck he likes, and the administrator who is constrained by all these duties is nonsense. It seems to me that English law is very clear: if I am in control of funds or assets I owe my duties to those who are entitled to the benefits of the fund; and whether I am called an administrator, receiver, trustee, director, or whatever is entirely irrelevant. I owe my duties to those who have an interest in the funds. So the idea that you have an administrator and somehow all these duties arise is nonsense in my opinion."

This interviewee suggests that a receiver is someone akin to a fiduciary. ${ }^{87}$ Indeed, while a receiver may be seen as a fiduciary with responsibilities towards persons who are beneficially entitled to the estate within his control, ${ }^{88}$ one can see why the judicial interpretation of these responsibilities (which indicates that they are primarily owed to the secured creditor to procure repayment of the debt ${ }^{89}$ ) would eventually be seen to be incompatible with a statutory insolvency framework predicated on collectivity. However, one could also argue that the report that led to the abolition of receivership placed great emphasis on receivers' obligations to their appointing creditors, while discounting their duties to wider stakeholders. A fortiori, case law has shown that the receiver also owes a duty to all other parties with an interest in

\footnotetext{
${ }^{87}$ The concept of fiduciary duties has previously been put forward in the context of pre-packs as a basis to challenge the legality of pre-packs and an administrator's decision to execute a pre-pack sale. See P Walton, 'Pre-packaged Administrations - Trick or Treat?' (2006) 19 Insolvency Intelligence 113, 116. See also Courtwood Holdings SA v Woodley Properties Ltd [2018] EWHC 2163 (Ch) at [131] - [138] where it was accepted that "... fiduciary duties typically arise where one person undertakes and is entrusted with authority to manage the property or affairs of another and to make discretionary decisions on behalf of that person ...."

${ }^{88}$ For a discussion of the nature of a receiver's duties, see n.39 above et seq.

${ }^{89}$ Gomba Holdings (UK) Ltd v Homan [1986] BCLC 331; Medforth v Blake [1999] 2 BCLC 221; Silven Property v Royal Bank of Scotland [2004] 1 WLR 997.
} 
the equity of redemption. ${ }^{90}$ This duty, depending on powers exercised by the receiver in the particular insolvency scenario, carries with it an obligation of care and accountability towards such interested parties. ${ }^{91}$ Therefore, to contend that the concept of receivership implicitly lacks accountability to a wider category of persons would be inaccurate. That said, one of the interviewees, a banker, had a differing opinion on this:

"On a wider holistic view of an insolvency process, I think an administrator who owes his duty to all creditors is a better thing. I always think of an insolvency process in exactly the way that you just put it: that it is akin to a trust and I think that is why an administrator who is sort of a trustee is desirable as the best or most appropriate solution. Because a receiver isn't that- they are not really a trustee in that sense - their job is narrow: sell the assets, get the best price, and return it to the appointing creditor."

Whether or not we can conceive an administrative receiver as being accountable to wider creditors, there still remains a practical question: does an administrator's duty under paragraph 3(2) make a difference to an office-holder's execution of the insolvent's estate in administration when compared to receivership? The interviewees were unanimous in saying that this duty makes very little difference in reality and it is worth reproducing the views of one of them, an insolvency practitioner, here:

"From an insolvency practitioner's objective-strategy point of view, what are you trying to do? Very little is different. Your responsibility in a receivership is to the charge holder with a secondary responsibility to all of

\footnotetext{
${ }^{90}$ Silven Property v Royal Bank of Scotland [2004] 1 WLR 997 at [22].

${ }^{91} \mathrm{ibid}$. This is in addition to the obligation on a receiver to exercise his powers in good faith and for a proper purpose, see Downsview Nominees Ltd v First City Corp Ltd [1993] AC 295. For a description of an administrative receiver's duty to provide his report to unsecured creditors, see Insolvency (England and Wales) Rules 2016, r 4.14.
} 
the creditors, whereas in administration it is to all of the creditors. But to be honest, you are trying to get as much money for all of the assets as you can. So, unless there is a conflict where getting more money for one asset damages another one and vice versa, most of the time, the stars are all aligned in the same way and you are just trying to maximise realisations for all assets and then distribute those ... It doesn't seem to me that [the duty under paragraph 3(2)] makes an awful lot of difference between having a principal duty to a charge holder and a secondary duty to everybody else. In many years, I cannot think of an instance where we are not actually working in the best interest of everybody and so I think what you say is right. In real practical terms, the receivership and administration that I have done in many years would probably have gone down a similar route whichever the process ... I always think that we acted in the interest of all creditors; whether individual creditors agreed with that might be a different matter. But I do not think that statement added much weight to what was already happening. At the end of the day, you have got some assets to realise and distribute to creditors; you have got a responsibility to get as much for those assets as you can and distribute out. Having that extra obligation under paragraph 3(2) did not really feel like it added more to what was already there: which was, a duty of care ..."

The picture that emerges from the views and discussions above is that there is minimal difference between the objectives and execution of an administration and receivership procedure. The subtle differential lies where the objective is to pursue a rescue of the company as a going concern, which stands in contrast with the ideals of receivership as a vehicle for marshalling the realisation of assets, and the wide powers of an administrator to 
put together a corporate rescue package. In any event, the receiver does not have a duty to consider a rescue of the company, nor is s/he required to trade at all. ${ }^{92}$

But given that the objective to rescue a company is rarely pursued in administration, we are faced with the reality that both insolvency procedures can be used as a debt recovery vehicle for the benefit of a qualifying floating charge holder. Indeed, this probability is expressly contemplated by the provision which permits an administrator, subject to certain caveats, ${ }^{93}$ to perform his functions with the objective of realising property in order to make a distribution to one or more secured or preferential creditors, ${ }^{94}$ along with the facility to make an out-of-court administrator appointment. Of course, where the objective to make a distribution to secured creditors is pursued, the duty in paragraph 3(2) is suspended. Moreover, the administrator, like a receiver, can be directly appointed by or at the request of the chargee. ${ }^{95}$ Perhaps then these blunt remarks of an interviewee, a lawyer, hold water:

\footnotetext{
"I think the abolition of administrative receivership was utterly pointless. It has achieved nothing at all; the same guys are doing the same job with a different hat on. What on earth is the point of doing that?"
}

One would like to think that a similar statement to that contained in paragraph 3(2) could have been imported into receivership to make it a procedure that overtly prioritises the interests of

\footnotetext{
${ }^{92}$ Ahmad v Bank of Scotland [2016] EWCA Civ 602 at [38].

${ }_{93}^{93}$ Insolvency Act 1986, Sch B1, para 3(4).

${ }^{94} \mathrm{ibid}$, para $3(1)(\mathrm{c})$. This outcome has led to the idea that administration is "receivership-plus" or simply a "transmutation of administrative receivership and administration". See G McCormack, 'Control and corporate rescue - an Anglo-American evaluation' (2007) ICLQ 515, 535-536.

${ }^{95}$ A discussion of tacit administrator appointments by debenture holders is to be found in Akintola, 'What is left of the Floating Charge? An Empirical Outlook', n.62 above, 405-406.
} 
all stakeholders. Indeed, there is evidence of statutory codification of a receiver's duty from other jurisdictions like Canada, ${ }^{96}$ New Zealand, ${ }^{97}$ and Ireland. ${ }^{98}$

Some comparison with LPA receivership is also apposite. LPA receivers just as administrative receivers, and administrators in many instances, are appointed out of court by the secured creditor. ${ }^{99}$ The LPA receiver is an agent of the debtor. ${ }^{100}$ This is another point of convergence with administrative receivership and administration. ${ }^{101}$ The cases show that there are duties owed by this receiver to the debtor (for example to be faithful and act in the debtor's interest), which emanate from that agency. ${ }^{102}$ Thus, there is nothing 'false' about the agency. The LPA receiver has a duty to account to the debtor, act in good faith in relation to any sale, and take reasonable care to obtain a proper price. ${ }^{103}$ These duties extend to other persons in very close proximity to the debtor, including a guarantor - if not to the general body of creditors of the debtor. ${ }^{104}$ Administrators, in comparison, owe no general common law duty of care to individual creditors in the conduct of the administration. ${ }^{105}$ There are also benefits in a LPA receivership to a secured creditor. For example, the appointment does not prevent the creditor from suing for the debt. ${ }^{106}$ Further, this receiver need not be an insolvency

\footnotetext{
${ }^{96}$ Bankruptcy and Insolvency Act 1992, s 247.

${ }^{97}$ Receiverships Act 1993, ss 18-19.

${ }^{98}$ Companies Act 2014, s 439.

${ }^{99}$ Although they are appointable in a mortgage made by deed to receive the income of a mortgaged property where the mortgage money has become due. See LPA 1925, s 101(1)(iii); Twentieth Century Banking Corporation Ltd v Wilkson [1977] Ch 99, 104D-E (Templeman J).

${ }^{100}$ LPA 1925, s 109(2).

101 Thus, LPA receivership is a statutory extension of the conveyancing practice discussed in the origins of receivership in section 1 above. See also Jefferys v Dickson (1866) 1 Ch App 183; Gaskell v Gosling [1896] 1 QB 669.

${ }^{102}$ Hibernian Bank v Yourell (No 2) [1916] 1 I R 312 (decided under the Conveyancing Act 1881). Decision restored by House of Lords in Yourell v Hibernian Bank [1918] AC 372. See also Re Kentish Homes Ltd [1993] BCC 212 at 220-221.

${ }^{103}$ A useful trawl of relevant cases and principles will be found in Devon Commercial Property Limited v Robert Adrian Barnett [2019] EWHC 700 (Ch).

${ }^{104}$ Standard Chartered Bank Ltd $v$ Walker and Anor [1982] 1 WLR 1410 at 1415 . Further, a creditor who interferes with the realisation process runs the risks associated with being labelled a "mortgagee in possession".

${ }^{105}$ Charalambous v B\&C Associates [2013] BCC 491. See also Re Charnley Davies (No 2) [1990]

BCLC 760.

${ }^{106}$ Lynde $v$ Waithman [1895] 2 QB 180.
} 
practitioner nor do statutory obligations (such as payment of preferential debts ${ }^{107}$ and statutory reporting obligations ${ }^{108}$ ) apply to this form of receivership. ${ }^{109}$ The LPA receiver can be removed by the secured creditor without leave of the court. ${ }^{110}$ Some of these features suggest that LPA receivership could provide a cheaper resolution of a distressed entity's affairs. Finally, while the LPA receiver is statutorily limited to collecting the income arising from the mortgaged property, this statutory power could be contractually extended in the debenture to enable the receiver realise other assets and manage the debtor's business.

To conclude, our view is that there is little substantive distinction between administrative receivership and administration. ${ }^{111}$ This is reinforced by the fact that both the receiver and administrator act as the company's agent. ${ }^{112}$ As we have seen, the commercial manifestations of this agency are seldom different in reality. Any stark differentiation would lie in the fact that only a court-appointed receiver - and not an administrative receiver - is an officer of the court and inherently subject to the court's supervision, ${ }^{113}$ whereas an administrator is an officer of the court (whether or not he is appointed by the court). ${ }^{114}$ Further, unlike administration, receivership is not classed as collective insolvency proceedings for the purpose of the EU Regulation on Insolvency Proceedings (2015/848). ${ }^{115}$

\footnotetext{
${ }^{107}$ Since the security will not necessarily involve a floating charge - Insolvency Act 1986, s 40.

${ }^{108}$ Insolvency Act 1986, ss 46-48.

${ }^{109}$ Such receivers might, however, be regulated by professional bodies like The Association of Property and Fixed Charge Receivers (NARA). See Business, Innovation and Skills Committee, Oral Evidence: Insolvency (HC 936-i, 4 March 2015).

${ }^{110}$ LPA 1925, s 109(5); $c f$ Insolvency Act 1986, s 45(1).

${ }^{111}$ At least in terms of strategies adopted by office-holders in both procedures and rescue or asset sale outcomes. This is without prejudice to the plethora of procedural distinction between both procedures, including an administrator's powers and reporting obligations to creditors. See Davey v Money and Anor [2018] EWHC 766 (Ch) at [254].

${ }^{112}$ Insolvency Act 1986, s 44; Sch B1, para 69. See also D Milman 'Receivers as Agents' (1981) 44 MLR 658.

${ }^{113}$ For the implications of a court-appointed receiver being an officer of the court, see Glatt v Sinclair [2013] EWCA Civ 241; Wood v Gorbunova [2013] EWHC 1935 (Ch). As an officer of the court, the receiver will be required to act honourably; see Ex parte James (1874) LR 9 Ch App 609.

${ }^{114}$ Insolvency Act 1986, s 44; Sch B1, para 5.

${ }^{115}$ But it could continue to matter in broader cross-border insolvency contexts as there is also a lack of recognition under the UNCITRAL Cross-Border Insolvency Regulations 2006 (SI 2006/1030).
} 
Whether or not this exclusion would continue to matter under this framework will depend on the outcome of the Brexit negotiations. Finally, as we have noted, a procedural differential between the two regimes lies in the fact that there is no time limit in receivership, unlike in administration. ${ }^{116}$

\section{Solvent Receiverships}

So far in our discussion we have examined the use of receivership as a remedy for secured ${ }^{117}$ creditors of insolvent companies to facilitate debt recovery. That has been the paradigm case of the usage of receivership in English Company Law. But paradigms can be misleading if they disguise the overall scenario. On closer examination it is apparent that there are other situations where the receivership remedy can be deployed in respect of a company and its assets.

The best example is where receivership is used as an interim measure to protect a company that is the subject of a damaging internal dispute. We are talking here about caretaker receivership in respect of a solvent company. Companies comprise of networks of stakeholders often with 50/50 interests and sometimes it is necessary to keep warring stakeholders apart to preserve the integrity of the company. This makes economic sense for all concerned and the court may appoint a receiver to do just that. This remedy has been available since the dawn of modern company law ${ }^{118}$ under the inherent jurisdiction of the

\footnotetext{
${ }^{116}$ Insolvency Act 19876, Sch B1, para 76.

${ }^{117}$ Unsecured creditors, without more, cannot seek the appointment of a receiver. As receivership is inextricably linked to the floating charge, and as partnerships cannot grant floating charges, there are no cases of receiverships of insolvent partnerships.

${ }^{118}$ Early examples of its possible usage are to be found in the judgments of Malins VC in his judgments in Featherstone v Cooke (1873) LR 16 Eq 298 and Trade Auxiliary Co v Vickers (1873) LR $16 \mathrm{Eq} 303$. The protective aspect of this solution is stressed as is its temporary element. Later examples of receivership being utilised in this way are to be found in Stanfield v Gibbon [1925] WN 11 (P.O. Lawrence J), Re Hannetta Ltd (1953) 216 Law Times Jo 639 (Roxburgh J) and MGMv Elliott, The Times October 26th 1966, [1966] CLY 1392 (Court of Appeal). In the latter case a receiver was appointed in the context of a joint venture dispute over the distribution rights of a film (ironically entitled "The Liquidator").
} 
court and is now explicitly recognised by s. 37 of the Senior Courts Act 1981 and rule 69 of the Civil Procedure Rules. For example, in Re A Company (00596 of 1986) ${ }^{119}$ Harman J acceded to an application to appoint a receiver and manager for a short period pending the resolution of a dispute that had resulted in an unfair prejudice petition being presented under what is now s. 994 of the Companies Act 2006. Harman J felt that there was sufficient authority to justify such a disposition. In particular, the company could be viewed as a quasipartnership and partnership law accepted such a possibility. ${ }^{120}$ Again, in BAT Industries plc v Windward Prospects $L t d^{121}$ the issue was whether the court should appoint an interim receiver with a view to protecting claims for the recovery of dividends which it was alleged had been improperly paid out. Hamblen $\mathrm{J}$ felt that in the absence of an undertaking that these claims would be pursued by the directors, then such an appointment would be appropriate.

Receivership is not explicitly listed in s. 996 of the Companies Act 2006 as one of the indicative remedies which the court might grant in the wake of a successful unfair prejudice petition, but it is submitted that it may be available in that context, particularly on an interim basis. However, it is unlikely to feature as a long-term remedy to resolve a case of unfair prejudice. If things have become so bad between the disputing stakeholders, and no resolution is in sight, the most likely outcome would be a winding up on the just and equitable ground pursuant to s. 122(1)(g) of the Insolvency Act 1986.

That said, the courts are very careful about utilising this remedy with respect to a solvent company. Their main concern lies in the stigma associated with the term

\footnotetext{
119 (1986) 2 BCC 99,063. For a comparable Australian authority see Duffy $v$ Super Centre Development Corp Ltd [1967] 1 NSWR 382 (Street J). Note also Verhelst v Going Places (1980) ACLC 34,138, Cape v Redarb Pty (1992) 10 ACLC 1273.

${ }^{120}$ For examples of potential partnership receivership situations see Floydd $v$ Cheney [1970] 2 WLR 314 (Megarry J) and Sobell v Boston [1975] 1 WLR 1587 (Goff J). The reluctance to appoint a partnership receiver, which was apparent in those cases, is also manifested in Toker $v$ Akgul (unreported CA, 2 November 1995) [1996] CLY 4540 and Don King Productions Ltd $v$ Warren [1999] 2 Lloyds Rep 392.

${ }^{121}$ [2013] EWHC 3612 (Comm). Note also the observations of Norris $\mathrm{J}$ in Catch a Ride Ltd $v$ Gardner [2014] EWHC 209 (Ch).
} 
"receivership", which has come to be associated in commercial minds with the idea of corporate financial distress. Ferris J emphasised this concern in Jaber v Science and Info Tech Ltd. ${ }^{122}$ Placing a solvent company into receivership could be the kiss of death by destroying its goodwill in the eyes of the outside world. ${ }^{123}$ Such a step therefore needs to be carefully handled. Cost considerations are also relevant. ${ }^{124}$ Very often an equivalent but less expensive protective remedy can be put in place using injunctions and even freezing orders. ${ }^{125}$ These may cause less reputational damage.

There are other situations where the remedy of receivership might be deployed in a corporate context. So, receivership may be used to support a process of equitable execution in respect of the enforcement of a judgment debt which has not been settled by the debtor. After some uncertainty about the availability of jurisdiction to do this under the Judicature Acts, this possibility is now well settled. ${ }^{126}$ One point to bear in mind is that a debtor's shareholdings are themselves assets against which execution can be enforced. ${ }^{127}$ A receiver appointed in such circumstances operates in personam and does not enjoy rights in security. ${ }^{128}$ In Masri v Consolidated Contractors International UK Ltd ${ }^{129}$ the Court of Appeal confirmed that it had the power to appoint a receiver to collect an income stream generated from a foreign asset where the debtor had submitted to the jurisdiction of the English courts.

\footnotetext{
122 [1992] BCLC 764. See also McLean v Valken Property Pty Ltd (1983) 1 ACLC 1320 where this factor persuaded the court not to appoint.

${ }^{123}$ That said, if the receivership is effective the company can always change its name to put distance between itself and the firm that went into receivership.

${ }^{124}$ Evans LJ stressed this in Toker v Akgul (supra). See also Laffoy J in the High Court of Ireland in Haughey $v$ Synnott [2011] IEHC 467 (another partnership dissolution case).

${ }^{125}$ But a freezing order and receivership are not mutually exclusive options - see Derby $v$ Weldon (Nos 3 and 4) [1990] 1 Ch 65.

${ }^{126}$ For a manifestation of this jurisdictional confusion see Harris v Beauchamp [1894] 1 QB 801, Re Swallow Footwear Ltd, The Times October 23rd 1956, [1956] CLY 1242 (Roxburgh J). A recent example of this type of receivership affecting a company is provided by VB Football Assets $v$ Blackpool Football Club (Properties) Ltd [2019] EWHC 530 (Ch).

${ }^{127}$ Shareholdings may be made subject to a charging order as an alternative to the use of receivership.

${ }^{128}$ See Stevens v Hutchinson [1953] Ch 299.

${ }^{129}$ [2008] EWCA Civ 303. See also Fonu v Merrill Lynch Bank and Trust Co (Cayman) Ltd [2011] UKPC 17 and Blight $v$ Brewster [2012] EWHC 165 (Ch).
} 
Again, in Cruz City 1 Mauritius Holdings v Unitech Ltd ${ }^{130}$ Males $\mathrm{J}$ accepted the possibility of appointing a receiver over the overseas assets of a foreign company in circumstances where that debtor company was deemed to have submitted to the jurisdiction of the English courts by it accepting a London arbitration of a dispute.

There is one common thread in these cases of receivership noted above; the involvement of the court as the facilitator of the process. Any receiver so appointed would be an officer of the court and so be subject to the duty to act honourably. ${ }^{131}$ But the protection offered by the law of contempt would be available. There is no evidence of any out of court usage of the receivership regime in this context, though it is submitted that if the parties have agreed via contract, such an appointment may be possible, for example as part of an ADR process. Principles of open justice would, therefore, not be engaged.

\section{E. Conclusion}

Our discussions above suggest that there is still life left in receivership as a remedy in UK Corporate Law, broadly conceived. Specifically, we have presented receivership as a versatile process that is capable of delivering individual or collective relief in insolvent and solvent contexts. However, and despite its sporadic usage in insolvency contexts, it would seem that much of the negative narrative that enshrouded insolvent company receiverships could be stifling its utility in a solvent company context.

If this is so, and the caution exhibited by Ferris $\mathrm{J}$ in Jaber $^{132}$ becomes the norm, then it is our view that receivership may have some untapped potential in the solvent company context. The best exemplar of this is the warring stakeholders in a trading company scenario.

\footnotetext{
${ }^{130}$ [2014] EWHC 3131 (Comm), [2015] 1 BCLC 377.

${ }^{131}$ Ex parte James (1874) LR 9 Ch App 609. In practice this is a weak duty that permits the exercise of opportunism for the protection of the estate under the officer's control.

${ }^{132}$ See $n .113$ above et seq.
} 
Pending the resolution of the dispute, and, perhaps, the restructuring of the company's internal management, a neutral party such as a receiver could provide value by managing the company's property or business. Bare civil procedural remedies or orders like injunctions may preserve the status quo but are unlikely, without more, to generate commercial value from the assets to which they attach. A receiver could plug this gap.

UK Corporate Law will not be a unicorn should it holistically embrace receivership again. There are countries where receivership is still recognised and deployed. We have already given the examples of Canada, New Zealand and Ireland which statutorily prescribe a receiver's duty to a wider category of stakeholders. ${ }^{133}$ A further example is Cyprus, where receivership is a viable option except during or in the eve of an examinership. ${ }^{134}$ Finally, there is data to support the ongoing - even if limited - use of receivership in Australia, notwithstanding the prescience of an administration regime. ${ }^{135}$ Therefore, in our view, we should not write off receivership. Institutions adapt to meet changing circumstances. This is particularly apposite in the current insolvency climate where there is ample concern on the value and cost of administration. We have already suggested in section $\mathrm{C}$ that receivership could be a cheaper procedure to operate than administration. It is therefore more efficient. Looking at future developments, the outcome of Brexit could cause administration to lose some competitive advantage over receivership. Further, the volte face on preferential claims ${ }^{136}$ might lead to banks arguing that the EA 2002 "settlement" with the government be revisited.

\footnotetext{
${ }^{133}$ See n.100-n.102 above.

${ }^{134}$ Companies (Amendment) (No. 2). Law of 2015, CAP. 113 Part IVA, s 202H (2). Even then, the court may permit a receiver to continue to act in certain circumstances or concerning certain assets; see s 202I.

${ }^{135}$ Some figures for appointment of receivers and receiver-managers are as follows: 2015-2016 (588); 2016-2017 (400); and 2017-2018 (393). Information available at < https://download.asic.gov.au/media/4925756/asic-insolvency-statistics-series-2-published-november2018.pdf $>$ accessed 30 November 2018.

${ }^{136}$ HM Treasury, Budget 2018 (HC 1629, October 2018), 3.87.
} 
However, a holistic reaffirmation of receivership in the UK would be best served by Parliamentary prescription of a receiver's duty of care, status as an officer of the court, as well as enhancing the transparency of the receiver's conduct particularly when a going-concern sale of the business is brokered. ${ }^{137}$

This, of course, will not address concerns around receivership's compatibility with the rescue culture that is ostensibly driven by the Enterprise Act 2002. Such concerns will be accentuated by the connection between rescue and the protective effect of a moratorium, which receivership implicitly lacks. Nevertheless, it is difficult to suggest that the postEnterprise Act administration procedure is a vehicle that necessarily delivers corporate rescue. As we noted in section $\mathrm{C}$ above, the objective to rescue the company itself is rarely pursued. Rather, like receivership, what is more common is the sale of the company's assets on a break-up basis or the rescue of the business as a going concern. Another marked point is the realisation, borne by empirical data, that a number of post-Enterprise Act administrations are "disguised liquidations"; that is to say cases that prior to the Enterprise Act would have been carried out as liquidation but have gone into administration as a result of the ability to initiate the procedure out of court. ${ }^{138}$ Perhaps then, it is time to drop the narrative of one procedure delivering a better outcome than the other. The outcome in either procedure will be tied to the commercial reality of the case in question.

\section{Word Count: 10,531}

\footnotetext{
${ }^{137}$ Possibly something akin to a SIP 16 report. This would align with current plans to reinforce the rescue culture by reforming our insolvency frameworks to include "... a range of transparent rescue procedures". See Department for Business, Energy \& Industrial Strategy, Insolvency and Corporate Governance - Government Response (August 2018), p.8. Available at <https://www.gov.uk/government/consultations/insolvency-and-corporate-governance> accessed 20 October 2018.

${ }^{138}$ S Frisby, 'The Effect of the Enterprise Act: Empirical Research into Corporate Insolvency' in W-G Ringe, L Gullifer and P Thery (eds), Current Issues in European Financial and Insolvency Law (Hart 2009), ch 3, pp 58-59.
} 